Jolanta Kruk

ORCID: 0000-0001-9599-0446

Wyższa Szkoła Bankowa w Gdańsku

jkruk@wsb.gda.pl

Mariola Palka-Pilecka

ORCID: 0000-0002-9662-4410

Wyższa Szkoła Bankowa w Gdańsku

mpalka@wsb.gda.pl

\title{
Problematyka relacji osobowych w ujęciu Janusza Korczaka w odniesieniu do wychowawców i nauczycieli. Rekonstrukcja teoretyczno-empiryczna
}

\section{Summary \\ Pupil and teacher personal relationships in Janusz Korczak's view. The theoretical and empirical reconstruction}

Janusz Korczak's works and pedagogical activities can be perceived on different levels. This text is a proposal of the analysis of Korczak's achievements in the context of building personal relationships in the process of educating with respect to alumni and teachers-educators. In Conclusions the created reconstruction of the way Janusz Korczak understood mutual relations was interpreted in the context of the idea of dialogical personalism. It is a theoretical and empirical article based on Korczak's works, the materials collected during a visit to Korczakianum. The method applied in this reconstruction was the fusion of the analysis of selected works and the open interview with the managers of this research lab ${ }^{1}$.

Keywords: Janusz Korczak, educator/teacher, alumnus/pupil, relation, dialogical personalism

Słowa kluczowe: Janusz Korczak, wychowawca/nauczyciel, wychowanek/uczeń, relacja, personalizm dialogiczny

\section{Wprowadzenie}

Janusz Korczak jako praktyk, a zarazem teoretyk poruszał te zagadnienia, które w swojej działalności wychowawczej uważał za szczególnie ważne z perspektywy niekwestionowanego podmiotu wychowania, jakim jest dziecko. Każdy swój wykład, odczyt czy publikację opierał na przykładach czerpanych z praktyki, wydobywał z nich szczegóły, aby

1 The interview with Marta Ciesielska, the principal of Korczakianum, and Anna Czernow was conducted on 25th of March 2019. Korczakianum is a division of the Museum of Warsaw. 
następnie wyprowadzić z nich to, co istotne. Uczył nauczycieli, jak poznawać dziecko oraz jak poznawać samego siebie, aby budować wzajemne relacje, przy czym podkreślał, że są to relacje równe pod względem osobowym. W artykule zastanawiamy się, na czym polegał fenomen sukcesu wychowawczego Korczaka, a zwłaszcza - w jaki sposób kształtowały się jego więzi z wychowawcami. Korczak był nie tylko towarzyszem dziecięcego losu, ale też wnikliwym nauczycielem dorosłych - właśnie ta relacja jest przedmiotem niniejszej refleksji².

\section{Nota metodologiczna}

Analizowany materiał badawczy stanowią głównie wybrane fragmenty tekstów Janusza Korczaka oraz zapisanych wypowiedzi osób go znających, opisujące go od strony jego praktyki nauczycielskiej, oraz materiał zdjęciowy zebrany przez autorki w trakcie wizyty w Korczakianum. Ponadto analizie poddano dane uzyskane z wywiadu otwartego przeprowadzonego w Korczakianum z Martą Ciesielską oraz Anną Czernow. Korczakianum jest obecnie częścią Muzeum Warszawy; mieści się w przekształconym niegdysiejszym Domu Sierot, zbudowanym w 1912 roku przez Towarzystwo „Pomoc dla Sierot”, przeznaczonym dla dzieci potrzebujących opieki. Jego modernistyczny kształt w zasadzie sprzyjał założonym funkcjom, jednak - jak mówi Marta Ciesielska - „Korczak kilka lat później, tuż po wojnie, pisał, że teraz, gdyby znów budował taki dom, to wyglądałby on zupełnie inaczej; nie te wielkie otwarte sypialnie, lecz pokoje hotelowe. W 1928 roku już inaczej zbudowano dom na Bielanach [Nasz Dom], inaczej rozplanowany, bardziej funkcjonalny" (Wywiad - Ciesielska: 1,28').

Przeprowadzony w tym historycznym budynku z zachowanymi pomieszczeniami dawnego Domu Sierot wywiad stał się poruszającym doświadczeniem poczucia uczestnictwa w życiu dawnych jego mieszkańców ${ }^{3}$. Współczesne funkcjonowanie obiektu, w którym siedzibę mają dwie niezależne placówki o różnym kształcie i wewnętrznej organizacji, odbiega od pierwowzoru. Nadal jednak stanowi niezwykły projekt łączący cechy użytkowe (jako główny użytkownik znajduje się tu Zespół do Obsługi Placówek Opiekuńczo-Wychowawczych nr 2 z wchodzącym w jego skład Domem Dziecka nr 2 im. Janusza Korczaka) oraz ekspozycyjno-dokumentacyjne i naukowo-wydawnicze. Obecnie Korczakianum działa jako ośrodek archiwalny, informacyjno-konsultacyjny i badawczy zajmujący się spuścizną Korczakowską, prezentowaną także w postaci stałej symbolicznej wystawy.

Od chwili wejścia do Korczakianum zwiedzający ma poczucie przebywania w przestrzeni przygotowanej do ekspozycji dokumentacji poświęconej Korczakowi. Znajdujące się w przestrzeni ekspozycyjnej (centralna sala budynku) obiekty to głównie zapisy wspomnień, reprodukcje fragmentów dokumentów i planów, mapy oraz inne teksty i po-

\footnotetext{
2 Korczak jako wykładowca nie jest dobrze znany odbiorcom jego dzieł. $Z$ tego powodu podjęłyśmy się analizy jego relacji z dorosłymi uczącymi się - z przyszłymi wychowawcami.

3 Warto nadmienić, że do tej pory dawny Dom Sierot, mieszczący się obecnie przy ul. Jaktorowskiej (dawna ul. Krochmalna 92), nie został wpisany do rejestru historycznego dziedzictwa narodowego.
} 
większenia zdjęć. W zasadzie nie ma tu żadnych przedmiotów związanych z mieszkańcami Domu Sierot, ponieważ nieliczne zachowane oryginalne pamiątki to zdjęcia i książki (przechowywane w pracowniach). Zwiedzanie Korczakianum pobudza do refleksji o tym miejscu, skłania do odkrywania myśli towarzyszących dawnym uczestnikom życia domu przy Krochmalnej: dzieci, wychowawców, Stefanii Wilczyńskiej i Janusza Korczaka. Jak Stary Doktor sam mówił: „Dom Sierot nie był, nie jest, i nigdy nie będzie domem Korczaka" (Wywiad - Ciesielska: 28,59').

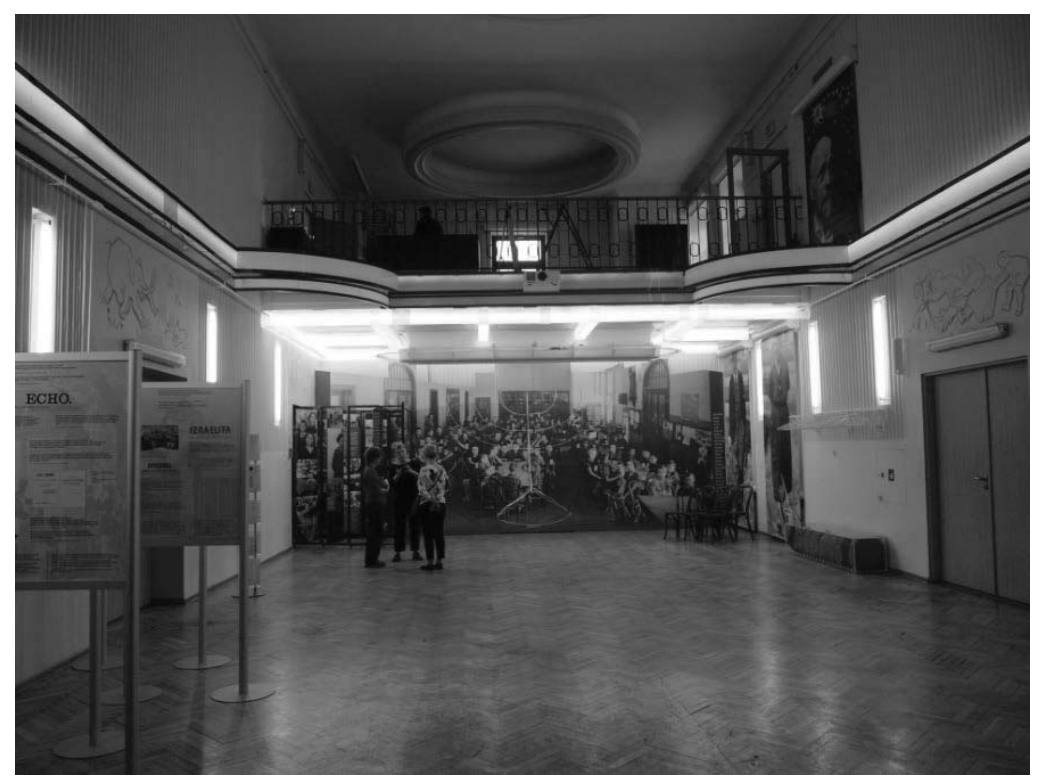

Fot. 1. Korczakianum (dawny Dom Sierot), od lewej stoją: Anna Czernow, Marta Ciesielska, Mariola Pałka-Pilecka

Źródło: Fotografia zamieszczona dzięki uprzejmości pani M. Ciesielskiej.

Naszym zadaniem było znalezienie w wybranych tekstach, wspomnieniach i wypowiedziach wątków obrazujących sposób bycia zamieszkujących tam osób i wzajemnego tworzenia więzi. Aby pogłębić możliwe odpowiedzi, w pierwszym etapie zrekonstruowałyśmy warstwę formalną dotyczącą działalności publikacyjnej i wykładowczej Korczaka, następnie dokonałyśmy przeglądu jego tekstów w konfrontacji z wybranymi tekstami innych pedagogów, szczególnie Marii Grzegorzewskiej. Ten wątek dotyczy też poglądów Korczaka na pracę z przyszłymi pedagogami. W dalszej części próbujemy dokonać pewnych syntez, ukazujących istotę myśli Korczakowskiej w wymiarze ogólnoludzkim. W tym celu nawiązujemy do nurtu filozofii personalistycznej i dialogicznej, traktując je jako możliwy trop interpretacyjny. Wywiad otwarty stanowi w tym kontekście pewien stabilizator zbyt daleko idących uogólnień bądź uproszczeń. $Z$ tej perspektywy uznajemy, że: „Ludzie, jako podmioty działania, nie są zwykłymi nosicielami struktur, lecz aktywnymi 
twórcami tego, co społeczne, są więc depozytariuszami istotnej wiedzy, którą można ująć tylko od wewnątrz" (Kaufmann 2010: 37, 38).

\section{Wyklady, odczyty i publikacje Korczaka dla nauczycieli}

Wykłady dla nauczycieli oraz publicystyka pedagogiczna Korczaka były ściśle powiązane z jego działaniem. W latach międzywojennych, od 1922 roku, wykładał w Państwowym Instytucie Pedagogiki Specjalnej (PIPS) oraz w Państwowym Instytucie Nauczycielskim (PIN) - uczelniach zajmujących się kształceniem nauczycieli, założonych i kierowanych przez Marię Grzegorzewską. Spis tematów zajęć, które Korczak prowadził w PIPS, obejmuje zagadnienia interesujące z punktu widzenia tematu niniejszego artykułu, m.in. $\mathrm{Na}$ uczyciel a wychowawca, Wady i zalety wychowawcy, Poznanie dzieci i dziecka (Korczak 1928/1929: 157-158). Od 1925 roku do końca lat dwudziestych Korczak wykładał przedmiot: Prawa dziecka jako jednostki na kursach dokształcających dla wychowawców zakładów opiekuńczo-wychowawczych, które były organizowane przez Ministerstwo Pracy i Opieki Społecznej (Babicki 1928: 314). W latach dwudziestych prowadził też zajęcia z psychologii w szkole pielęgniarskiej Towarzystwa Przyjaciół Dzieci, kierowanej przez Annę Braude-Hellerową, oraz na seminariach nauczycielskich, m.in. w Prywatnym Seminarium Ochroniarskim. Od 1927 roku prowadził też wykłady z przedmiotu Społeczeństwo dziecięce w Studium Pracy Społeczno-Oświatowej, zorganizowanym przez Helenę Radlińską w Wolnej Wszechnicy Polskiej (Kirchner (red.) 2017: 360). Korczak uczestniczył również w różnych inicjatywach, na których wygłaszał referaty i odczyty, np. cykl odczytów pt. Dziecko krzywdzone zorganizowanych przez Polski Komitet Pomocy Dzieciom (Kirchner (red.) 2017: 368, 373).

Wiedzę na temat wykładów Korczaka można uzyskać z protokołów i sprawozdań, ze wspomnień studentów - słuchaczy czy innych pedagogów, szczególnie Marii Grzegorzewskiej, ale przede wszystkim z publikacji artykułów w czasopismach specjalistycznych oraz z napisanych przez Korczaka książek skierowanych do rodziców i wychowawców - nauczycieli.

O Korczaku są takie wspaniałe wspomnienia jako o nauczycielu - wykładowcy, wykładał przecież w różnych instytucjach kształcenia czy doskonalenia nauczycieli i te relacje są takie, że choć był przecież znanym autorytetem, publiczną osobą i tak dalej, to nie dominował - że ludzie się przy nim czuli bardzo „pobudzeni”, otwarci, bezpieczni - to jest właśnie budowanie bezpiecznej przestrzeni mentalnej, że możesz wypowiedzieć się swobodnie, bo nikt/nic cię nie ośmieszy... To nie tylko dotyczy relacji z dzieckiem, to dotyczy też relacji „,dorosły-dorosły” (Wywiad - Ciesielska: 60’).

Czasopiśmiennictwo pedagogiczne z okresu międzywojennego rozwijało się równolegle z systemem kształcenia nauczycieli i wychowawców w powstających licznie od 1919 roku seminariach nauczycielskich, a następnie liceach pedagogicznych oraz $\mathrm{w}$ różnych instytucjach służących doskonaleniu zawodowemu nauczycieli czynnych (Dereń 2011). Periodyki pedagogiczne stanowiły płaszczyznę komunikowania się osób naukowo i prak- 
tycznie zaangażowanych w myśl pedagogiczną, dając możliwość powstawania różnych środowisk edukacyjnych. „Szeroką działalność wydawniczą rozwijał Związek Nauczycielstwa Polskiego ${ }^{4}$, który w różnych okresach wydawał 80 czasopism" (Jarowiecki 1983: 89), w tym w ramach Sekcji Szkolnictwa Specjalnego czy Sekcji Wychowawczyń Przedszkoli. Korczak opublikował najwięcej artykułów, bo aż 20 tekstów w latach 1925-1939 w kwartalniku „Szkoła Specjalna”, najpewniej ze względu na długoletnią współpracę z Marią Grzegorzewską i wykłady prowadzone w PIPS (tam też mieściła się redakcja pisma). Poza tym publikował również w takich pismach, jak „Wychowanie Przedszkolne”, „Przedszkole”, „Wychowawca”, „Głos Nauczycielski”, „Praca Szkolna”, „Dos Kind” i inne (Kirchner (red.) 2017: 369, 378-381). Doświadczeniem pedagogicznym i lekarskim dzielił się też w publikacjach zamieszczanych w czasopismach: „Opieka nad Dzieckiem”, „Życie Dziecka”, „Dziecko i Matka”. Umieścił także recenzję, która dotyczyła wyboru pism Stefana Żeromskiego obrazujących konieczność poprawy losu dziecka i roli wychowawców w tym zakresie w miesięczniku „Książka”, poświęconym krytyce i bibliografii (Kirchner (red.) 2017: 362).

Już w zarysie wspomnianych periodyków widoczne jest połączenie praktyczno-teoretycznego doświadczenia autora publikacji. Sam Korczak w jednym z artykułów zawarł często cytowane słowa: „Dzięki teorii wiem, dzięki praktyce czuję” (Korczak 1924/1925: 87). Równolegle w swojej działalności naukowej apelował, aby autorytety naukowe uznawały ważne przesłanie praktyki pedagogicznej, ponieważ on w swoim doświadczeniu jako wieloletni wychowawca w ten sposób doszedł do prawd zawartych w teoretycznych opracowaniach. Uznawał też za konieczność w regule akademickiej takie działania jak: „rozważania zadań praktycznych (...), przymus pisania, podatek doświadczenia" (Korczak 1926/1927: 138). W swojej wrażliwości jako człowiek, jako pedagog i lekarz odkrywał to, co dotyczyło dzieci, a wobec czego nie chciał pozostać obojętny.

Działalność Korczaka jest opisywana głównie jako „wychowawcy dzieci”, natomiast w mniejszym stopniu postrzega się go jako „wychowawcę wychowawców” (Kirchner (red.) 2017: 367) czy „nauczyciela nauczycieli” (Frączek 2013:311), a przecież prowadził „rozważania o tym, kim jest i kim bywa wychowawca i czym może być dla niego teoria pedagogiczna, czego i jak uczy praktyka, jak można i trzeba uczyć się także od dzieci" (Kirchner (red.) 2017: 367-368). Odwołując się do praktyki wychowawczej, stawiał więc pytanie o naturę relacji pomiędzy nauczycielem/wychowawcą a uczniem/wychowankiem. W swoim przekazie do wychowawców zwraca uwagę na elementy zagrażające zbudowaniu głębokiej relacji osobowej lub wręcz ją uniemożliwiające. Za istotne uważał uznanie przez wychowawcę jego odpowiedzialności za jakość budowanej relacji z uczniem, bo to wychowawca - według Korczaka - „ma obowiązek być umiejętnym organizatorem warunków, w których dziecko w pełni swych praw może swobodnie się rozwijać" (Korczak 2017: 313). Z jednej strony relacji osobowej pomiędzy wychowawcą a wychowankiem stoi więc dziecko, którego wartość osobowa domaga się respektowania, a z drugiej - jest

4 Związek Nauczycielstwa Polskiego przechodził różne zmiany, w tym także dotyczące nazwy. Do 1930 roku funkcjonował jako Związek Polskiego Nauczycielstwa Szkół Powszechnych. 
wychowawca, którego zadaniem jest dbałość o jej jakość w każdej sytuacji edukacyjnej z każdym indywidualnym wychowankiem. Stąd wynikają dla wychowawcy zadania wobec wychowanka oraz wobec samego siebie (zob. Łobocki 1997: 239). W niniejszym artykule staramy się dokonać rekonstrukcji Korczakowskich zasad budowania relacji w stosunku do dorosłych.

\section{Relacje i więzi z wychowawcami}

Kształtowaniu się poglądów na tworzenie relacji z wychowankami towarzyszyło krystalizowanie się podejścia Korczaka do kształcenia studentów pedagogiki i nauczycieli - przyszłych wychowawców. Na tej płaszczyźnie jego dokonania zasługują również na szczególną uwagę, ponieważ łączył wiedzę teoretyczną ze wskazaniami i obserwacjami praktycznymi oraz jako człowiek - wychowawca - wykładowca - lekarz był „człowiekiem prawdy i głębokiego poczucia odpowiedzialności" (Grzegorzewska 1958: 58). W opinii Grzegorzewskiej:

Wykłady Korczaka to nie teoretyzowanie, nie gotowe formuły, nie rozważania płynące z wiedzy książkowej - to mówił mądry wychowawca o uczeniu się na błędach i powodzeniach, o poznawaniu życia w jego normalnym rozwoju, w codziennej, ustawicznej pracy, to jego ciągłe poszukiwania, dochodzenia, badania w przeżywaniu z dziećmi ich zajęć, trosk, radości, rozczarowań i zachwytów. Zjawiały się na wykładach tych jak gdyby wizje żywych dzieci i współżyjącego z nimi badacza - wychowawcy... (Grzegorzewska 1958: 56-57).

To, w jaki sposób Korczak prowadził wykłady, ich treść i forma przekazu oraz sama istota spotkania ze studentami pedagogiki i nauczycielami - wszystko to razem stanowiło naukę budowania relacji osobowej pedagoga $\mathrm{z}$ dzieckiem.

Istotną cechą u Korczaka była spójność prezentowanych koncepcji i poglądów z osobistą postawą, dzięki czemu każde spotkanie z nim było ważne dla słuchaczy, a jego przekaz odbierany jako autentyczny:

Nie powinno być rozdźwięku między słowami a czynami wychowawcy (Korczak 1938: 286).

Był swojego rodzaju artystą w nawiązywaniu kontaktu ze słuchaczami. (...) W sposób niesłychanie prosty mówi rzeczy ważkie i głębokie. (...) Działał nie tylko treścią, ale i formą wypowiadania myśli. Formą, która działała tak sugestywnie, że ma się wrażenie obcowania $\mathrm{z}$ autorem i przeżywania z nim razem wszystkich poruszanych zagadnień. (...) Staje się nam od razu bliski i jemu można by właśnie wszystko bez skrępowania powiedzieć, o wszystko zapytać, o wszystko w dziedzinie wychowania się poradzić (Grzegorzewska 1958: 57-59).

Zauważano, że Korczak szukał sposobów wzbudzania potencjału osobowego u studentów i słuchaczy seminariów. Znakomitym przykładem jest wykład „Serce dziecka” wygłoszony w Państwowym Instytucie Pedagogiki Specjalnej: 
Wszyscy słuchacze zdziwieni tym zarządzeniem zebrali się w pracowni rentgenologicznej - mówi jedna z ówczesnych słuchaczek - Doktor przyszedł tam z jakimś chłopcem ze swojego sierocińca. Puszczono w ruch aparat, żeby zobaczyć serce dziecka - zatrwożone, szybko bijące w tej chwili serce. Chłopiec bał się - tyle obcych osób, ciemna sala, maszyna huczy. - „Tak wygląda serce dziecka w chwili, gdy wychowawca gniewa się na nie". Nie trzeba było bliższych komentarzy - tę lekcję wszyscy pamiętają do dzisiaj (Grzegorzewska 1958: 56).

Zachęcał do poznawania siebie samego jako osoby wychowawcy, a równocześnie do łagodności wobec siebie, wobec własnych błędów oraz bardzo wysokich wymagań, refleksji i rzetelnej pracy. Za ważne uznawał zrozumienie motywów swojego zachowania, prawdę o sobie samym i pamięć o własnym dzieciństwie, co pomagało mu zrozumieć sposób odczuwania dziecka.

Takie błędy i uchybienia występują w pierwszych dniach pracy wychowawczej. To boli, ale jednocześnie uczy. Będzie jeszcze więcej błędów. To nie do uniknięcia. Dlatego jest tak ważne, aby każdy wychowawca, który przystępuje do pracy w jakimś zakładzie, jeszcze raz się zastanowił: do czego zmierza w życiu, co chce osiągnąć. Najgorsze - to niepewność i chwiejność. Każdy dzień pracy bez dokładnego planu jest przewlekłą chorobą, infekcją moralną. Tak gasną i znikają nadzieje... (Korczak 1937: 273).

Największym wrogiem wychowania jest pośpiech. Jeśli mam coś powiedzieć - lepiej później; mam czas pomyśleć, wybrać odpowiednią chwilę, a przede wszystkim sam się uspokoję (Korczak 1927: 130).

Z trzech źródeł czerpię pobłażanie, z trzech krynic - wyrozumiałość dla dziecka: Znam niedomogi warunków, własne braki. Przywołuję wspomnienia nie zawsze anielskiego dziecięctwa. Przez mgłę gęstą, sięgając w przyszłość, pytam się: - Ile goryczy wypijesz ty, jak ja piję, mój nieświadomy nieopatrzny, niedoświadczony młodszy bracie - dziecko? (Korczak 1919: 11).

Uważał za konieczny ciągły rozwój kompetencji wychowawczych, zwłaszcza wrażliwego poznawania potrzeb dziecka, do czego niezbędna jest wnikliwa obserwacja szczegółów, momentów, kontekstów, które wychowawca musi zapisywać, żeby następnie poddawać je refleksji, wnioskowaniu prowadzącym do zrozumienia i właściwego działania wobec tego konkretnego wychowanka.

Dziecko jest dla wychowawcy księgą natury: czytając dojrzewa. Nie wolno lekceważyć dziecka. Ono wie więcej o sobie, niż ja wiem o nim (Korczak 1925/1926: 101).

Dla mnie, a zapewne dla każdego wychowawcy, nie ma „dzieci”, są osobniki tak odmienne, tak krańcowo różne, tak każde inaczej i w sposób swoisty reaguje na to, co je otacza... (Korczak 1978: 348). 
W internacie dla małolatów zapisywałem przy każdym posiłku: kto ile razy płakał i ile razy przez niego płakali. Nie zapomnę chwili, gdy pięcioletni Zozur - bandyciak, zerwał się z ławki, mocno objął mnie za szyję i oblewając zupą z łyżki, powiedział szczęśliwym szeptem do ucha: - „Ja dziś ani razu nie płakał i przeze mnie nikt ani razu nie płakał” (Korczak 1926: 108).

Każdy wychowawca znać winien stenografię: poznaliśmy szczere relacje dzieci (Korczak 1935: 223).

Czym gorączka, kaszel, wymioty dla lekarza, tym uśmiech, łza, rumieniec dla wychowawcy. Nie ma objawu bez znaczenia. Trzeba notować i zastanawiać się nad wszystkim, odrzucać, co przypadkowe, łączyć, co pokrewne, szukać kierujących praw (Korczak 2017: 9).

Drogą samowychowania i samozmagań sam w sobie, młody wychowawco. Poprzez długi szereg iluminacyj, coraz wyższych szczebli - wspinasz się mozolnie ku rozumieniu mowy szeptu, uśmiechu, spojrzenia, gestu - łzy skruchy lub niemocy - dziecka występnego (Korczak 1925/1926: 102-103).

Uznawał więc siebie za człowieka/wychowawcę będącego w procesie rozwoju, a swoim doświadczeniem dzielił się z przyszłymi nauczycielami:

Charakterystyczne dla narracji Korczaka w jego pismach jest to, że on często odwołuje się do nieudanych doświadczeń (...), dzieli się doświadczeniem i w bólu rodzi się prawda: i nie bój się, nie rozpaczaj, jeżeli coś nie wyjdzie, bo dobry wychowawca tym się różni od złego, że nie powiela błędów, ale to nie znaczy, że jest wolny od błędów (...) wyciągaj wnioski z doświadczeń, przepracowuj, proponuj coś innego, idź za głosem dzieci, a może one ci wskażą, co było nie tak, i buduj to krok po kroku, bo nie ma nic od razu (Wywiad Ciesielska: 36,50 ').

Zacytowane poglądy znajdują kontynuację we współczesnych interpretacjach sposobu widzenia praktyki wychowania przez Korczaka:

Świetne Momenty wychowawcze! Myślę, że na studiach ze studentami powinno się je czytać, (...). To są kapitalne obserwacje dziecka w sytuacji szkolnej, a jednocześnie samoobserwacja obserwującego. Jakieś dziecko, dziewczynka, zgłasza się - a my już wiemy, że ona nigdy nic... To pierwsze wrażenie - pisał Korczak o sobie, że przecież nie chciał tego odnotować: ,przecież ja już ją znam, ja wiem, ja już mam tę etykietę w głowie, a tu nagle ta dziewczynka, beznadziejna, a zgłasza się...”. Tak sobie ułatwiamy życie, a potem narzekamy, że dzieci są nieaktywne, że nie uczestniczą... Nie dajemy przestrzeni, nie cenimy aktywności, jeżeli nie jest ona przez nas oczekiwana (Wywiad - Ciesielska: 40’).

Tymczasem właśnie takie momenty mogą być punktem zwrotnym dla wychowawcy dającego dziecku szansę rozwojową: 
Kto czuwając nad powierzonymi mu dziećmi, nie zdobędzie się na wysiłek krytycznego stosunku do własnej osoby, temu grozi duże niebezpieczeństwo, na które pragnę zwrócić uwagę, tym bardziej że higiena zawodowa ducha nie dość jest ogółowi znana. Wychowawca w pracy nad zrozumieniem człowieka - dziecka i społeczeństwa - gromady dzieci, dorasta do wtajemniczeń ważkich i cennych: zlekceważywszy czujność i pracę nad sobą - upada. Dziecko daje mi doświadczenie, wpływa na moje poglądy, świat moich uczuć; od dziecka otrzymuję nakazy dla siebie, żądam, oskarżam się, pobłażam lub rozgrzeszam. Dziecko poucza i wychowuje (Korczak 1925/1926: 101).

Korczak wskazuje tym samym, że człowiek jako osoba i człowiek jako student, wychowawca, nauczyciel jest potencjalnością w permanentnym rozwoju, a relacja z dzieckiem jest relacją wzajemności i nadaje dorosłemu kierunek jego wzrostu osobowego i zawodowego.

\section{Próba podsumowania: rekonstrukcja rozumienia przez Janusza Korczaka wzajemnych relacji osobowych w kontekście myśli personalno-dialogicznej}

Z działalności publicystycznej i akademickiej Janusza Korczaka można wywieść zasady, które determinowały sposób budowania przez niego relacji osobowej. Otóż po pierwsze warunkowała ją autentyczność osoby wychowawcy przez spójność jej poglądów i postaw. Godności Korczak uczył przez godne traktowanie każdego człowieka - dziecka i dorosłego. Jak wspomina go Grzegorzewska:

Korczak wyzwalał prawdę już wprost obecnością swoją. Każdy w obcowaniu z nim stawał się sobą - był sobą. Tęskniło się wprost do prostoty i czystości myśli, które niosły ludziom, prócz smutku i zadumy, jego dziwnie dobre oczy. Spojrzenie to onieśmielało, zmuszało jak gdyby błyskawicznie do rachunku sumienia z sobą samym (...). Spojrzenie wnikliwe, głębokie, pełne dobroci, ale i jak gdyby sprawdzających zapytań - pełne przy tym wyrozumiałości dla błędów i małości człowieka... (...) idący w pracy swoją drogą rzetelności, prawdy i sprawiedliwości (Grzegorzewska 1958: 59).

Relacja dla Korczaka była spotkaniem z dzieckiem konkretnym, a nie abstrakcyjnym. Podkreślał, że:

Zobaczyć dziecko takim, jakim ono jest istotnie, i dziecko, i dzieci, i każde z nich. Nauczyć rodziców, wychowawców i nauczycieli patrzeć na nie z bliska swoimi oczami i widzieć je w ich różnorodności w życiu, a nie spoglądać na nie z oddali poprzez kartki teorii i widzieć jak gdyby, także różnorodne, ale papierowe szablony (Korczak 1925/1926: 54).

Sam Korczak stanowił dla swoich wychowanków i współpracowników jedność i uobecniał porządek wartości dojrzałego człowieka, z którym spotkanie miało moc budowania i podnoszenia. 
Poszukując kontekstu dla myśli Korczaka, można zauważyć, że odnajdujemy go w personalistycznym i dialogicznym nurcie filozofii i pedagogiki. W myśli personalistycznej dostrzegamy afirmację przez Korczaka wartości i godności osoby i domaganie się takiego samego wrażliwego stosunku do dziecka. Z takiego stanowiska wydają się wynikać zasady, którymi się kierował w budowaniu relacji z każdym człowiekiem - z wychowankiem, współpracownikiem, przyszłym czy aktualnym pedagogiem - studentem i słuchaczem seminarium nauczycielskiego. Personalizm właśnie, mimo różnorodności odmian, w każdym z nich w centrum swojej refleksji stawia człowieka jako osobę, swoją nazwę bowiem wywodzi od tego pojęcia - łac. persona (do jego przedstawicieli można zaliczyć: Charles'a Renouviera, Maxa Schelera, Emmanuela Mouniera, Jacques'a Maritaina, Karola Wojtyłę) (Adamski 2005: 11). Personalistyczne ujęcie osoby podkreśla jej ontologiczną wartość (przysługującą z natury, z samego faktu bycia osobą) oraz jej dynamiczną naturę, wyposażoną w potencjalności, które aktualizują się w procesie wychowania i samowychowania. Warto tu przytoczyć zbieżne z poglądami Janusza Korczaka stanowisko Mariana Nowaka, który podkreśla wartość osoby ludzkiej, postawę szacunku wobec specyficznego misterium (tajemnicy) osoby wychowanka, stanowiącej pierwszy i podstawowy faktor (czynnik) wychowania, oraz rolę wychowawcy jako kooperatora procesu wychowania i kompetentnego reprezentanta kulturowej tradycji (Nowak 2000: 258). Respektowania tego właśnie domagał się Korczak:

Korczak (...) reagował na wszelkie takie teksty, które słyszał co i rusz. I piszą o tym jego wychowankowie, jak wychowawca powiedział dziecku: „(...) ja ci tu daję jeść, a ty jesteś nieposłuszny”. Potrafił zareagować (...): „Gdyby nie te dzieci, to wy byście nie mieli tej pracy”. Odwracał ten porządek, który (...) do dzisiaj jest aktualny (Wywiad - Czernow: $\left.32,43^{\prime}\right)$.

Wychowawca nie odpowiada przed społeczeństwem za dzieci, jak je sformatuje, ale odwrotnie - wychowawca odpowiada przed dziećmi za społeczeństwo (...). W regulaminie było napisane, że dyrektor i naczelna wychowawczyni (...) odpowiadają za przestrzeganie zasad obowiązujących w domu... (Wywiad - Ciesielska: 34,17').

Przestrzeń relacji międzyosobowych stała się przedmiotem zainteresowania personalizmu dialogicznego (Kowalczyk 2010: 117) jako nurtu filozoficznego i powiązanej z nią pedagogiki dialogu (reprezentowanych przez Martina Bubera, Józefa Tischnera, Tadeusza Gadacza, Janusza Tarnowskiego, Joannę Rutkowiak) (Milerski 2016: 24-26). „Współczesna dialogika bazuje na klasycznej filozofii dialogu Martina Bubera, dla którego »każde prawdziwe życie jest spotkaniem«" (Buber 1992: 45). Charakterystyczne cechy określonej przez Bubera relacji Ja-Ty, takie jak uznanie odrębności, autonomii, „inności” osoby, brak wszelkich zapośredniczeń, współobecność, wzajemność i odpowiedzialność (Buber 1992: 45-49; Kowalczyk 2010: 120-121), odnajdujemy nie tylko w żywej więzi Korczaka z wychowankami, ale też z osobami dorosłymi. 
W relacjach z dziećmi/wychowankami, ze studentami i wychowawcami oraz współpracownikami w środowisku akademickim Korczak był spójnym osobowo człowiekiem: skromnym, życzliwym, odpowiedzialnym i otwartym na własny rozwój - uczył się od dzieci budowania z nimi adekwatnych relacji, a swoim doświadczeniem potrafił się również kompetentnie i rzetelnie dzielić ze współczesnymi mu i przyszłymi pedagogami.

\section{Literatura}

Adamski F. (2005), Wprowadzenie: personalizm - filozoficzny nurt myślenia o człowieku i wychowaniu. W: F. Adamski (red.), Wychowanie personalistyczne. Warszawa, Wydawnictwo WAM.

Babicki C. (1928), Kursy dokształcające dla wychowawców zakładów opiekuńczo-wychowawczych. Uzasadnienie i program. W: H. Kirchner (red.), Janusz Korczak. Teoria a praktyka. Artykuty pedagogiczne (1919-1939). Warszawa, Wydawnictwo IBL PAN.

Buber M. (1992), Ja i Ty. Wybór pism filozoficznych. Warszawa, Instytut Wydawniczy PAX.

Dereń E. (2011), Kształcenie nauczycieli szkót powszechnych (podstawowych) lata 1918-1939. https:/sites.google.com/site/ksztalcenienauczycieli/organizacja-ksztalcenia-nauczycieli/lata1918-1939, 9.04.2019.

Frączek A. (2013), Zastużeni dla pedagogiki specjalnej. „Szkoła Specjalna”, 4.

Grzegorzewska M. (1958), Listy do Młodego Nauczyciela. Cykl II. Warszawa, PZWS.

Jarowiecki J. (1983), Bibliografia polskich czasopism pedagogicznych (do 1979). Stefan Możdżé, Julia Musiat, Kielce 1981 [rec.]. „Kwartalnik Historii Prasy Polskiej”, 22(3).

Kaufmann J.C. (2010), Wywiad rozumiejacy. Warszawa, Oficyna Naukowa.

Kirchner H. (red.) (2017), Janusz Korczak. Teoria a praktyka. Artykuły pedagogiczne (1919-1939). Warszawa, Wydawnictwo IBL PAN.

Korczak J. (1919), Źródła wyrozumiałości. „Głos Nauczycielski”, 8. W: H. Kirchner (red.), Janusz Korczak. Teoria a praktyka. Artykuly pedagogiczne (1919-1939). Warszawa, Wydawnictwo IBL PAN

Korczak J. (1924/1925), Teoria i praktyka. „Szkoła Specjalna”, 2, I-III. W: H. Kirchner (red.), Janusz Korczak. Teoria a praktyka. Artykuty pedagogiczne (1919-1939). Warszawa, Wydawnictwo IBL PAN.

Korczak J. (1925/1926), Wychowanie wychowawcy przez dziecko. „Szkoła Specjalna”, 2, I-III. W: H. Kirchner (red.), Janusz Korczak. Teoria a praktyka. Artykuly pedagogiczne (1919-1939). Warszawa, Wydawnictwo IBL PAN.

Korczak J. (1926), Skarga. „Wychowanie Przedszkolne”, 6, czerwiec. W: H. Kirchner (red.), Janusz Korczak. Teoria a praktyka. Artykuty pedagogiczne (1919-1939). Warszawa, Wydawnictwo IBL PAN.

Korczak J. (1926/1927), Kasta autorytetów. „Szkoła Specjalna”, 4, VII-IX 1927. W: H. Kirchner (red.), Janusz Korczak. Teoria a praktyka. Artykuły pedagogiczne (1919-1939). Warszawa, Wydawnictwo IBL PAN

Korczak J. (1927), Dwa razy dwa - cztery (Jak wychowywać dziecko). „Praca Szkolna”, 4, 30 IV. W: H. Kirchner (red.), Janusz Korczak. Teoria a praktyka. Artykuty pedagogiczne (1919-1939). Warszawa, Wydawnictwo IBL PAN. 
Korczak J. (1928/1929), Zasady wychowania w internatach. „Szkoła Specjalna”, 3-4, IV-IX.W: H. Kirchner (red.), Janusz Korczak. Teoria a praktyka. Artykuty pedagogiczne (1919-1939). Warszawa, Wydawnictwo IBL PAN.

Korczak J. (1935), Radio dla dzieci. „Pion”, 42, 19 X. W: H. Kirchner (red.), Janusz Korczak. Teoria a praktyka. Artykuly pedagogiczne (1919-1939). Warszawa, Wydawnictwo IBL PAN.

Korczak J. (1937), Nowy wychowawca. „Das Kind”, 2, październik. W: H. Kirchner (red.), Janusz Korczak. Teoria a praktyka. Artykuty pedagogiczne (1919-1939). Warszawa, Wydawnictwo IBL PAN.

Korczak J. (1938), Wychowawca a dziecko. (Notatki z rozmów seminaryjnych). „Unzer Frajhajt”, 2, kwiecień. W: H. Kirchner (red.), Janusz Korczak. Teoria a praktyka. Artykuły pedagogiczne (1919-1939). Warszawa, Wydawnictwo IBL PAN.

Korczak J. (1978), Jak kochać dziecko. W: A. Lewin (red.), Janusz Korczak. Pisma wybrane. T. 1, Warszawa, Nasza Księgarnia.

Korczak J. (2017), Momenty wychowawcze. Warszawa, Dragon.

Kowalczyk S. (2010), Nurty personalizmu. Od Augustyna do Wojtyly. Lublin, Wydawnictwo KUL.

Łobocki M. (1997), Przygotowanie nauczycieli do osobowej relacji z uczniem. W: W.M. Wołoszyn (red.), Aksjodeontologiczne aspekty relacji osobowych w procesach edukacyjnych. Bydgoszcz, Wydawnictwo WSP.

Milerski B. (2016), Pedagogika dialogu jako pedagogika hermeneutyczna. W: D. Jankowska, M. Grzelak-Klus (red.), Pedagogika dialogu. Dialog jako droga rozumienia i samorozumienia. Warszawa, Wydawnictwo APS.

Nowak M. (2000), Podstawy pedagogiki otwartej. Lublin, RW KUL.

Wywiad z Martą Ciesielską oraz Anną Czernow, przeprowadzony 25 marca 2019 r., Korczakianum, Warszawa. 